\title{
Nanotheranostics
}

2017; 1(2): 141-153. doi: 10.7150/ntno.18897

\section{Satellite-like Gold Nanocomposites for Targeted Mass Spectrometry Imaging of Tumor Tissues}

Yu-Ting Tseng1, Scott G. Harroun², Chien-Wei Wư1, Ju-Yi Mao³, Huan-Tsung Chang1, ${ }^{\bowtie}$, and Chih-Ching Huang $3,5,6 \bowtie$

1. Department of Chemistry, National Taiwan University, Taipei 10617, Taiwan;

2. Department of Chemistry, Université de Montréal, Montréal, Québec H3C 3J7, Canada;

3. Department of Bioscience and Biotechnology, National Taiwan Ocean University, Keelung 20224, Taiwan;

4. Department of Chemistry, Chung Yuan Christian University, Taoyuan City 32023, Taiwan;

5. Center of Excellence for the Oceans, National Taiwan Ocean University, Keelung 20224, Taiwan;

6. School of Pharmacy, College of Pharmacy, Kaohsiung Medical University, Kaohsiung 80708, Taiwan.

$\varangle$ Corresponding authors: Huan-Tsung Chang, Department of Chemistry, National Taiwan University, 1, Section 4, Roosevelt Road, Taipei 10617, Taiwan; tel. and fax: 011-886-2-3366-1171; e-mail: changht@ntu.edu.tw; Chih-Ching Huang, Department of Bioscience and Biotechnology, National Taiwan Ocean University, 2, Beining Road, Keelung 20224, Taiwan; tel.: 011-886-2-2462-2192 ext 5517; fax: 011-886-2-2462-2320; e-mail: huanging@ntou.edu.tw

(c) Ivyspring International Publisher. This is an open access article distributed under the terms of the Creative Commons Attribution (CC BY-NC) license (https://creativecommons.org/licenses/by-nc/4.0/). See http://ivyspring.com/terms for full terms and conditions.

Received: 2016.12.23; Accepted: 2017.02.25; Published: 2017.03.30

\begin{abstract}
We have developed a simple, rapid, high-throughput cancer diagnosis system using functional nanoparticles (NPs) consisting of poly(catechin) capped-gold NPs (Au@PC NPs) and smaller nucleolin-binding aptamer (AS1411) conjugated gold NPs (AS1411-Au NPs). The AS1411-Au $\mathrm{NPs} / \mathrm{Au} @ P C \mathrm{NP}$ is used as a targeting agent in laser desorption/ionization mass spectrometry (LDI-MS)-based tumor tissue imaging. Self-assembled core-shell Au@PC NPs are synthesized by a simple reaction of tetrachloroaurate(III) with catechin. Au@PC NPs with a well-defined and dense poly(catechin) shell $(\sim 40-60 \mathrm{~nm})$ on the surface of each Au core $(\sim 60-80 \mathrm{~nm})$ are obtained through careful control of the ratio of catechin to gold ions, as well as the $\mathrm{pH}$ of the reaction solution. Furthermore, we have shown that AS1411-conjugated Au NPs (13-nm) self-assembled on Au@PC NP can from a satellite-like gold nanocomposite. The high density of AS1411-Au NPs on the surface of Au@PC NP enhances multivalent binding with nucleolin molecules on tumor cell membranes. We have employed LDI-MS to detect AS1411-Au NPs/Au@PC NPs labeled nucleolin-overexpressing MCF-7 breast cancer cells through the monitoring of Au cluster ions $\left(\left[\mathrm{Au}_{n}\right]^{+} ; 1 \leq n \leq 3\right)$. The ultrahigh signal amplification from Au NPs through the formation of a huge number of $\left[\mathrm{Au}_{n}\right]^{+}$ions results in a sensing platform with a limit of detection of 100 MCF-7 cells $\mathrm{mL}^{-1}$. Further, we have applied the satellite-like AS1411-Au NPs/Au@PC NP nanocomposite as a labeling agent for tumor tissue imaging by LDI-MS. Our nanocomposite-assisted LDI-MS imaging platform can be extended for simultaneous analysis of different tumor markers on cell membranes when using different ligand-modified metal nanoparticles.
\end{abstract}

Key words: self-assembly, aptamers, gold nanocomposites, laser desorption/ionization mass spectrometry, tissue imaging

\section{Introduction}

Techniques for early cancer detection are important to reduce mortality rates of various cancers. Although traditional tissue section and cell morphological analysis can determine the degree of malignancy in clinical diagnosis, they are not sensitive enough for early cancer detection [1, 2]. Biomedical imaging techniques, including X-ray computed tomography, magnetic resonance, ultrasound, endoscopy, and nuclear medicine functional imaging such as positron emission tomography and single-photon emission computed tomography are widely assisted with tissue analysis in clinical 
decision-making for cancer diagnosis [3-6]. However, these imaging techniques for early diagnosis of cancer are limited due to low resolution, sensitivity, specificity and multiplexing ability. Thus, development of rapid, and highly specific imaging techniques with high resolution for early cancer detection remains a challenge.

Mass spectrometry imaging (MSI) has attracted much attention for analysis of biomolecules from tissue samples [7-11]. Many MSI techniques, including matrix-assisted laser desorption/ionization (MALDI) [12-14], matrix-free laser desorption/ionization [15, 16], laser ablation electrospray ionization and desorption electrospray ionization [17-25], and secondary ion [26-29] MS are employed for imaging or mapping of biomolecules in tissue samples. MSI is able to identify multiple biomolecules simultaneously, but it requires a large database for molecular identification and its sensitivity and resolution for large proteins (molecular weight $>80 \mathrm{kDa}$ ) are not great. The most convenient MALDI-MSI techniques are conducted in an organic matrix to assist desorption and ionization of biomolecules [12-14]. However, high background signals from the organic matrix sometimes hinder identification of compounds with low molecular weights. The laser desorption/ionization MS (LDI-MS) techniques could be employed for the analysis the distribution of nanomaterials in the cell and tissue samples [30,31]. Recently, nanomaterials and nanostructured substrates prepared from metal, metal oxide, silicon and carbon materials have been widely used as matrices in MS analysis to achieve higher resolution and lower background noise [32-39]. However, the LDI-MS techniques for tissue imaging can only detect highly abundant molecules, and therefore analysis of low-abundant proteins remains limited [40-43].

In this study, we have developed LDI-MS using functional nanocomposites for the detection of tumor cells and for tissue imaging (Scheme 1). Nucleolin binding aptamer (AS1411)-conjugated gold nanoparticles (AS1411-Au NPs) self-assembled on bigger core-shell gold-poly(catechin) nanoparticle $(\mathrm{Au} @ \mathrm{PC} \mathrm{NP})$ to prepare the functional nanocomposites (AS1411-Au NPs/Au@PC NP). Overexpression of nucleolin in some tumor cells was found to correlate with their longer half-life through binding to mRNA of Bcl-2 (an antiapoptotic protein) [44, 45]. We demonstrated by LDI-MS analysis that nanosatellite-like AS1411-Au NPs/Au@PC NP nanocomposites bind selectively to tumor cells, mainly through a strong affinity of AS1411 aptamer toward nucleolin on tumor cell membranes [dissociation constant $\left(K_{\mathrm{d}}\right)$ is in $\mathrm{pM}$ to low $\mathrm{nM}$ range] [46]. Gold cluster ions $\left(\left[\mathrm{Au}_{n}\right]^{+}\right)$derived from AS1411-Au NPs/Au@PC NPs under LDI act as amplified signal reporters for the detection of tumor cells and for obtaining tumor tissue images. The AS1411-Au NPs/Au@PC NPs coupled with LDI-MS can detect down to 100 cells $\mathrm{mL}^{-1}$ of breast tumor MCF-7 cells. This simple and sensitive LDI-MS platform can discriminate normal from cancerous breast tissues.

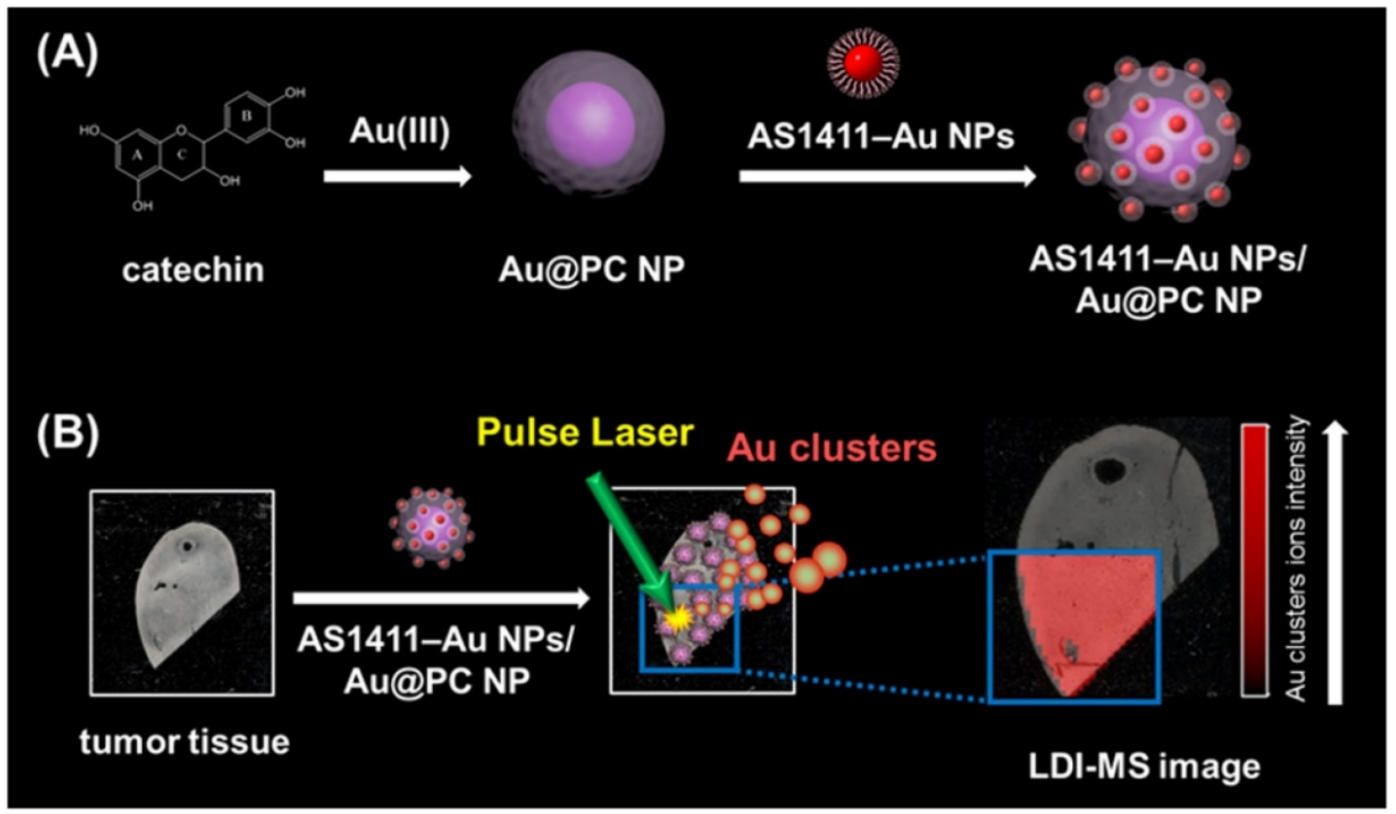

Scheme 1. Schematic representation of (A) the preparation of nucleolin-binding aptamer-modified gold nanoparticles (AS1411-Au NPs) and their conjugation to core-shell Au@poly(catechin) NP to form AS1411-Au NPs/Au@PC NP nanocomposite for (B) tumor tissue imaging through monitoring Au cluster ions by laser desorption/ionization mass spectrometry. 


\section{Experimental}

\section{Synthesis and Characterization of Core-shell Gold@poly(catechin) Nanoparticles}

Poly(catechin) capped-gold nanoparticles (Au@PC NPs) were synthesized by catechin-mediated reduction of $\mathrm{HAuCl}_{4}$. Tris-acetate buffer solution (100 $\mathrm{mM}, \mathrm{pH}$ 3.0-9.0, $1 \mathrm{~mL})$ and $\mathrm{HAuCl}_{4}(5.0 \mathrm{mM}, 1 \mathrm{~mL})$ were added to a $20-\mathrm{mL}$ vial containing deionized (DI) water $(3 \mathrm{~mL})$ with constant stirring. Then, freshly prepared catechin $(0.1-4.0 \mathrm{mM}, 5 \mathrm{~mL})$ was added and the stirring continued for $3 \mathrm{~h}$. The formation of $\mathrm{Au}$ NPs was indicated by the color change of the solution from yellow to brown/purple. The as-formed Au@PC NPs were purified via centrifugation [relative centrifugal force (RCF), 30,000 $\mathrm{g}$ ] for $20 \mathrm{~min}$, and the residue obtained was suspended in DI water. The purification process was repeated three times and the purified Au@PC NPs solutions were stored at $4{ }^{\circ} \mathrm{C}$ for $24 \mathrm{~h}$ before use. The particle sizes of Au@PC NPs were determined by transmission electron microscopy (TEM) (Tecnai 20 G2 S-Twin TEM, Philips/FEI, Hillsboro, OR, USA). The absorption spectra of the $\mathrm{Au} @ \mathrm{PC}$ NP solutions were recorded by a Synergy H1 multi-mode monochromatic microplate spectrophotometer (Biotek Instruments, Winooski, VT, USA). The X-ray diffraction (XRD) pattern of the $\mathrm{Au} @ P C$ NPs deposited on Si substrates was recorded using a PANalytical X'Pert PRO diffractometer (PANalytical B.V., Almelo, Netherlands) and $\mathrm{Cu}-\mathrm{Ka}$ radiation $(\lambda=0.15418 \mathrm{~nm})$. The particle concentration of Au@PC NP was determined assuming them as ideal spherical particles and by using eq. 1 .

$$
n=3 \mathrm{~m} / 4 \Pi r^{3} \mathrm{~s}
$$

where, $n$ is the number of $\mathrm{Au}$ particles per milliliter, $m$ is the concentration of gold in the substance $\left(\mathrm{g} \mathrm{mL}^{-1}\right), r$ is the particle radius $(\mathrm{cm})$, and $s$ is the specific gravity of colloidal gold $\left(19.3 \mathrm{~g} \mathrm{~cm}^{-3}\right)$. Values of $m$ and $r$ were determined via inductively coupled plasma mass spectroscopy (ICP-MS; PerkinElmer ELAN 6000, Waltham, MA, USA) and TEM measurements, respectively. For the convenience of calculation, the obtained concentration in particles per $\mathrm{mL}$ was converted into molar concentration, by first converting it into number of particles per liter, followed by dividing it by Avogadro's number.

\section{Preparation of Satellite-like AS1411-Au NPs/Au@PC NP Nanocomposites}

Spherical Au NPs having average size of $13.3 \mathrm{~nm}$ were prepared by the reduction of $\mathrm{HAuCl}_{4}$ with trisodium citrate (please see details in the Supporting Information). The modified AS1411 aptamer used in this study has the sequence 5'-AAA AAA AAA AAA AAA AAA AAG GTG GTG GTG GTT GTG GTG GTG GTG G-3', which is comprised of two blocks, a 20-repeat polyadenine $\left(\mathrm{A}_{20}\right)$ as an anchoring group to conjugate with $\mathrm{Au}$ NPs and a segment of the sequence providing AS1411 functionality. The functionalization of $\mathrm{Au}$ NPs with non-thiolated DNA was done by following previous reports with a slight modification [47-49]. Briefly, aqueous citrate-stabilized $\mathrm{Au} \mathrm{NP}$ solution was mixed with the AS1411 aptamer in $5 \mathrm{mM}$ sodium phosphate buffer ( $\mathrm{pH}$ 7.4) solution containing $50 \mathrm{mM} \mathrm{NaCl}$ in a $1.5 \mathrm{~mL}$ vial. The final concentrations of the Au NPs and the aptamer were $8 \mathrm{nM}$ and $2.0 \mu \mathrm{M}$, respectively. After $2 \mathrm{~h}$ of incubation, the aptamer-modified Au NPs were salt-aged for $12 \mathrm{~h}$ in $500 \mathrm{mM} \mathrm{NaCl}$ and centrifuged at RCF of $30,000 \mathrm{~g}$ for $20 \mathrm{~min}$ to remove the unreacted aptamers. After three centrifuge/wash cycles, the colloids were resuspended in mimetic physiological buffer solution [PBS; 25 mM Tris- $\mathrm{HCl}$ (pH 7.4), $150 \mathrm{mM} \mathrm{NaCl}, 5.0 \mathrm{mM}$ $\mathrm{KCl}, 1.0 \mathrm{mM} \mathrm{MgCl}_{2}$, and $1.0 \mathrm{mM} \mathrm{CaCl}_{2}$. To determine the number of aptamer molecules on each Au NP, the amount of aptamer in the supernatant after centrifugation was measured using OliGreen dyes. The 2-folded diluted supernatant was mixed with OliGreen (5000-fold diluted) in PBS. The DNA-OliGreen complexes fluoresce 1000-fold more intensely than does the free and weakly fluorescent OliGreen. The concentration of AS1411 was calculated by measuring the fluorescence of the mixtures at 524 $\mathrm{nm}$ (excitation wavelength: $480 \mathrm{~nm}$ ) with reference to a standard calibration curve. The nanosatellite AS1411-Au NPs/Au@PC NP was prepared by mixing $25 \mathrm{pM}$ dispersion of Au@PC NPs and $1.0 \mathrm{nM}$ of AS1411-Au NPs in PBS, followed by incubation for $12 \mathrm{~h}$ at room temperature to self-immobilize AS1411-Au NPs on Au@PC NP. The as-formed AS1411-Au NPs/Au@PC NP was stored at $4{ }^{\circ} \mathrm{C}$.

\section{Analysis of Tumor Cells by AS1411-Au NPs/Au@PC NP-LDI-MS}

Cultured MCF-10A, MDA-MB-231 and MCF-7 cell $(0-10,000$ cells, $1.0-\mathrm{mL})$ samples were labeled separately with AS1411-Au NPs/Au@PC NP or rDNA-Au NPs/Au@PC NP (5 pM; rDNA: random DNA with the same length as AS1411) for $1 \mathrm{~h}$ in PBS. A portion of each suspended solution $(1 \mathrm{~mL})$ was passed through a track-etched polycarbonate membrane (PCM; pore size: $5 \mu \mathrm{m}$, diameter: $13 \mathrm{~mm}$ ) by a syringe pump $\left(1 \mathrm{~mL} \mathrm{~min}^{-1}\right)$. The PCMs were then air-dried at room temperature for $10 \mathrm{~min}$. The nanocomposite-bound cells remained on the PCMs, and the PCMs were attached to a stainless-steel LDI plate for MS experiments. MS experiments were conducted using an Autoflex III LDI time-of-flight 
(TOF) mass spectrometer (Bruker Daltonics, Bremen, Germany) in the reflectron positive-ion mode. SmartBeam laser from Nd:YAG (355 nm) at $100 \mathrm{~Hz}$ was used for sample desorption and ionization. A delayed extraction period of 30 ns was set to energetically stabilize the ions produced by laser irradiation, before accelerating through the TOF chamber, and an accelerating voltage of +20 to $-20 \mathrm{kV}$ was applied. Before MS analysis, the instruments were calibrated with $\mathrm{Au}$ clusters using their theoretical masses. Samples were irradiated with 2000 pulsed laser shots at 10 LDI target positions at a power density of $5.0 \times 10^{4} \mathrm{~W} \mathrm{~cm}^{-2}$.

\section{Tissue Imaging}

Human breast tumor and normal breast tissue microarray (T087b; 6 cases; diameter: $1.5 \mathrm{~mm}$; thickness: $5 \mu \mathrm{m}$; US Biomax Inc., Derwood, MD, USA), human normal breast tissue section (BRE01; Pantomics Inc., Richmond, CA, USA), and human breast cancer section (BRE06; Pantomics Inc.) were used for tissue imaging. All the experiments involving tissue samples were conducted as per the protocols approved by the Animal Administration Committee of National Taiwan University. The tissue samples were deparaffinized and then labeled with AS1411-Au NPs/Au@PC NP, prepared from $0.2 \mathrm{nM}$ AS1411-Au NPs and 5 pM Au@PC NP, in PBS for $1 \mathrm{~h}$. The slide was washed three times with PBS before it was cast onto an MTP slide adapter II MALDI plate, and then air-dried at room temperature prior to LDI-MS measurements. LDI-MS imaging experiments were performed in the positive-ion mode using an Autoflex III LDI TOF mass spectrometer. The tissue slides were irradiated using a SmartBeam laser (355 nm Nd: YAG) operating at $100 \mathrm{~Hz}$. A laser spot diameter of $30 \mu \mathrm{m}$ and pixel step size of $150 \mu \mathrm{m}$ were employed. The ion extraction period and accelerating voltage range were same as that applied for tumor cell analysis by LDI-MS. Prior to analysis, the instruments were calibrated with $\mathrm{Au}$ clusters using their theoretical masses. One spot was pulsed for a total of 1000 laser shots at a power density of $5.0 \times 10^{4} \mathrm{~W} \mathrm{~cm}^{-2}$.

See the Supporting information for the details on the materials, preparation and characterization of $\mathrm{Au}$ NPs (13-nm), cell cultures, and immunohistochemistry.

\section{Results and discussion}

\section{Synthesis and Characterization of Au@PC NPs}

Core-shell Au@PC NPs were synthesized through a simple reaction of $\mathrm{HAuCl}_{4}$ with catechin, a polyphenolic flavonoid-type compound. The catechin acts as a reducing agent, while the as-formed poly(catechin) stabilize the nanocomposites. Oxidized catechin is suspected to self-polymerize to form poly(catechin), although the evidence for this reaction is indirect [50]. A series of Au@PC NPs were prepared by varying the $\mathrm{pH}$ value (3.0-9.0) of reaction solution and the molar ratio of catechin to $\mathrm{HAuCl}_{4}(0.1-4.0)$. The core-shell Au@PC NPs, after 3 h of reaction, were formed only under acidic solution conditions $(\mathrm{pH} \leq$ 5.0; Figure 1B, Supporting Information). The UV-vis absorption spectra of Au@PC NPs (synthesized at $\mathrm{pH}$ 3.0 and $\mathrm{pH} 5.0$ ) both show two distinct absorption bands at $\sim 575 \mathrm{~nm}$ and $\sim 385 \mathrm{~nm}$ (Figure 1A, Supporting Information), which are attributed to the surface plasmon resonance (SPR) absorption of the $\mathrm{Au}$ NP core and oxidized poly(catechin) shell, respectively [51]. It has been demonstrated elsewhere that the catechol B-ring of catechin $\left(3^{\prime}, 4^{\prime}\right.$-dihydroxyl moiety) possess stronger reducing ability than the resorcinol A-ring, and furthermore, that the reducing ability of catechin is $\mathrm{pH}$-dependent $[52,53]$. Catechin has a stronger reducing ability upon increasing $\mathrm{pH}$ value because deprotonation of the catechol groups boosts its electron-donating potency [52, 53]. Compared with $\mathrm{Au} @ \mathrm{PC}$ NP prepared at $\mathrm{pH} 3.0$ or $\mathrm{pH}$ 5.0, irregular $\mathrm{Au}$ NPs were formed at $\mathrm{pH} 7.0$ that have a wide size distribution (Figure 1B(c)), due to the higher growth rate of the gold core. As a result, poly(catechin) did not form a well dense shell on the surface of each $\mathrm{Au}$ core. Small-size, aggregated $\mathrm{Au}$ NPs $(\sim 8.8 \mathrm{~nm})$ were formed at $\mathrm{pH} 9.0$, probably due to the high nucleation rate of Au NPs and formation of less oxidized poly(catechin) to stabilize the Au NPs (Figure 1B(d)). Interestingly, we observed that the $\mathrm{Au} @ \mathrm{PC}$ NP prepared at $\mathrm{pH} 5.0$ has a raspberry-shaped gold core, compared to the rounder shape of that formed at $\mathrm{pH} 3.0$ (Figure 1B(a) and 1B(b)). A relatively fast reaction for growth of Au NPs at $\mathrm{pH} 5.0$ might be responsible for the formation of anisotropic raspberry-shaped gold cores.

We further investigated the effect of catechin concentration on the synthesis of Au@PC NPs. A series of $\mathrm{Au} @ \mathrm{PC}$ NPs were synthesized in Tris-acetate solution $(\mathrm{pH} 3,10 \mathrm{mM})$ with a constant concentration of $\mathrm{HAuCl}_{4}(0.5 \mathrm{mM})$ while varying the concentration of catechin (0.05-2.00 mM). Large-size Au NPs ( 90 $\mathrm{nm})$ without a poly(catechin) shell were observed when a low concentration of catechin was used (0.05 $\mathrm{mM}$; Figure S1B(a), Supporting Information). A dense of poly(catechin) shell is formed on the Au NPs when the concentration catechin is $0.5 \mathrm{mM}$ ([catechin] $/\left[\mathrm{HAuCl}_{4}\right]=1$ ), and the as-prepared $\mathrm{Au} @ \mathrm{PC}$ NPs show a narrow SPR band at $575 \mathrm{~nm}$, indicating that the Au@PC NPs were dispersed well in the solution (Figure S1(c)). Moreover, the shell of 
poly(catechin) becomes thinner, and a large degree of uncontrollable poly(catechin) sol appears at a higher concentration $(2.0 \mathrm{mM})$ of catechin; as shown in Figure S1B(e). The formation of poly(catechin) sol mainly arises through the autoxidation of excess catechin. We further studied Au@PC NPs that were synthesized at a constant molar ratio ([catechin] = $\left[\mathrm{HAuCl}_{4}\right]$; [catechin] $/\left[\mathrm{HAuCl}_{4}\right]=0.1,0.5,1.0$, or 5.0 $\mathrm{mM})$ in Tris-acetate solution $(\mathrm{pH} 3.0,10 \mathrm{mM})$. Under the optimized molar ratio of [catechin]/[ $\left.\mathrm{HAuCl}_{4}\right]$ and $\mathrm{pH}$ value, all synthesized Au@PC NP have an ideal spherical Au NPs core and condensed poly(catechin) shell, and much less uncoated poly(catechin) (Figure S2, Supporting Information). The core sizes and shell thickness of all synthesized Au@PC NPs are listed in Table S1 (Supporting Information). The size of core NPs and shell thickness of poly(catechin) determined by TEM are expressed as mean \pm standard deviations (100 counts). The representative histograms of the $\mathrm{Au} @ \mathrm{PC}$ NPs synthesized from $0.5 \mathrm{mM} \mathrm{HAuCl}$ and $0.5 \mathrm{mM}$ catechin in Tris-acetate buffer solution (10 $\mathrm{mM}, \mathrm{pH}$ 3.0-9.0) are shown in Figure S3 (Supporting Information). Overall, we can conclude that careful control of catechin concentration, the molar ratio of catechin to $\mathrm{Au}$ ions, and the solution $\mathrm{pH}$ results in the mediation of the nucleation and growth rates of $\mathrm{Au}$ NPs, and thereby varying the polymerization rate of oxidized catechin and the interaction of poly(catechin) with $\mathrm{Au}$ NP. Consequently, a well-defined poly(catechin) shell with a narrow-size distribution of Au NPs can be formed.

We further characterized the optimized Au@PC $\mathrm{NP}$ (core size $\sim 70 \mathrm{~nm}$, shell thickness $\sim 50 \mathrm{~nm}$ ), which were synthesized through the reaction of $\mathrm{HAuCl}_{4}(0.5$ $\mathrm{mM})$ with catechin $(0.5 \mathrm{mM})$ in $10 \mathrm{mM}$ Tris-acetate $(\mathrm{pH}$ 3.0). The optimized Au@PC NP has a zeta potential of ca. $-30 \mathrm{mV}$. The high zeta potential and a dense shell of poly(catechin) endow the Au@PC NP with stability in biological mimetic solution $[25 \mathrm{mM}$ Tris- $\mathrm{HCl}$ (pH 7.4), $150 \mathrm{~m} \mathrm{M} \mathrm{NaCl}, 5 \mathrm{mM} \mathrm{KCl}, 1 \mathrm{mM}$ $\mathrm{MgCl}_{2}, 1 \mathrm{mM} \mathrm{CaCl}, 100 \mu \mathrm{M}$ BSA; Figure S4, Supporting Information]. The X-ray diffraction (XRD) pattern of $\mathrm{Au} @ P C \mathrm{NPs}$ reveal that the $\mathrm{Au}$ core dominates the (111) crystal plane of fcc Au (Figure S5, Supporting Information). The poly(catechin) in $\mathrm{Au} @ \mathrm{PC}$ NPs is about $22 \mathrm{wt} \%$ as obtained from thermal gravimetric analysis (TGA) data (Figure S6, Supporting Information). Fourier transform infrared spectroscopy (FTIR) of Au@PC NP reveals a large number of phenolic $-\mathrm{OH}\left(3357 \mathrm{~cm}^{-1}\right)$ and aromatic $-C=C\left(1610 \mathrm{~cm}^{-1}\right)$ groups (Figure S7, Supporting Information), suggesting that the interaction Au@PC NP with AS1411-Au NPs is mainly through hydrogen bonding and $\pi-\pi$ stacking interactions.

(B)

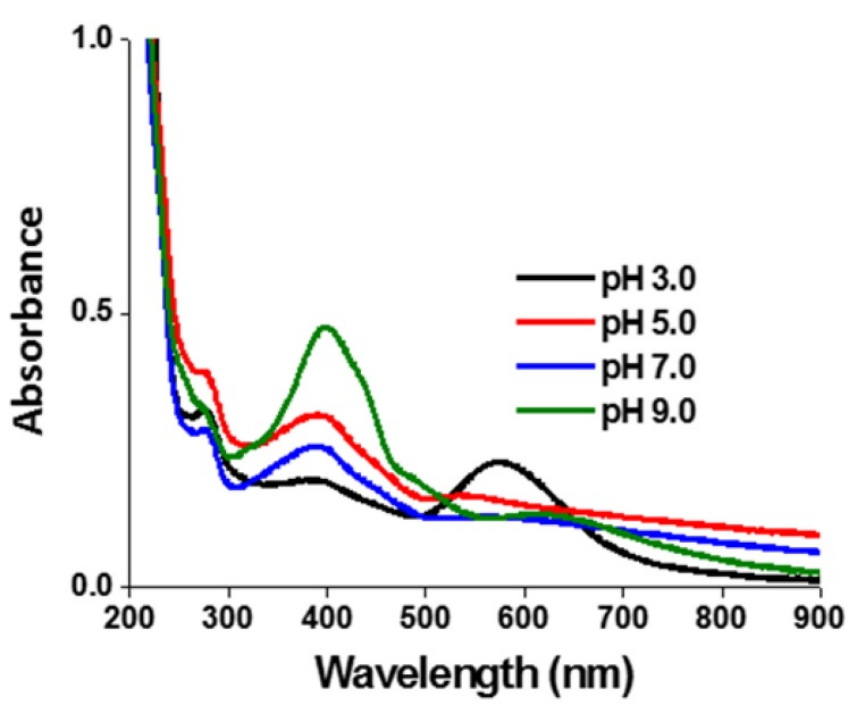

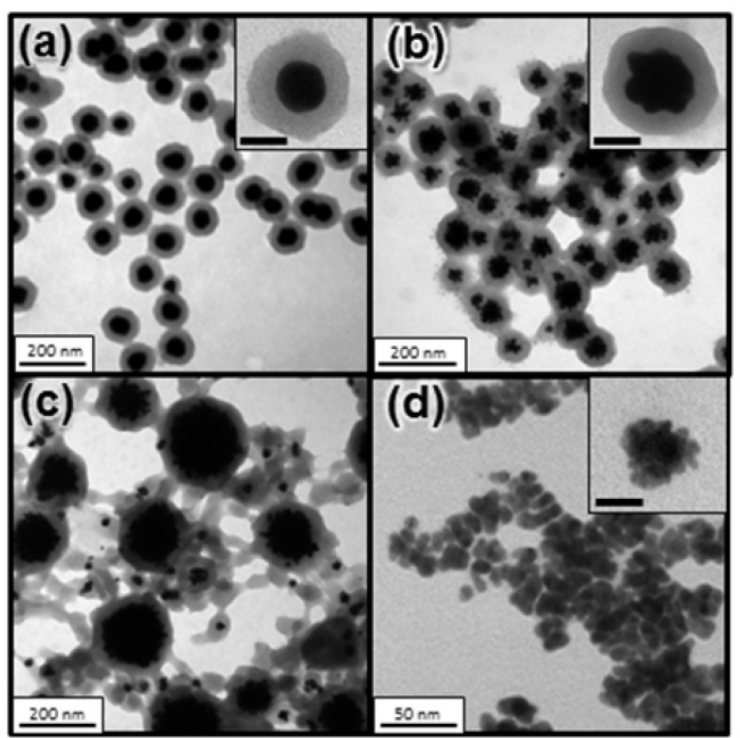

Figure 1. (A) UV-vis absorption spectra and (B) TEM images of the Au@PC NPs synthesized from $0.5 \mathrm{mM} \mathrm{HAuCl}_{4}$ and $0.5 \mathrm{mM}$ catechin in Tris-acetate buffer solution (10 mM) at (a) $\mathrm{pH}$ 3.0, (b) $\mathrm{pH} 5.0$, (c) $\mathrm{pH} 7.0$, and (d) $\mathrm{pH}$ 9.0. The insets to (B) show corresponding high-magnification TEM images. The scale bars in insets represent (a) $50 \mathrm{~nm}$, (b) $50 \mathrm{~nm}$ and (d) $5 \mathrm{~nm}$. 


\section{Preparation and Characterization of AS1411-Au NPs/Au@PC NP}

Aptamer-assembled Au NPs (AS1411-Au NPs) were obtained by mixing $\mathrm{Au}$ NPs (13-nm) with aptamer solutions, followed by salt-aging and purification. The number of AS1411 molecules on each NP was estimated by measuring the fluorescence of the supernatant after staining with OliGreen fluorescent dye, and found to be 30. Similar to $\mathrm{Au}-\mathrm{S}$ bonding, the polyA sequence at the $5^{\prime}$-terminus of the aptamer can preferentially bind with the Au NPs with high affinity [47-49]. Non-thiolated, poly(adenine)-terminal AS1411 aptamers are significantly cheaper than thiolated ones, and possess high flexibility after modifying the Au NPs [47, 48]. Moreover, the as-prepared AS1411-Au NPs remain stable in 2-fold diluted human plasma after $2 \mathrm{~h}$ incubation; the AS1411-Au NPs are not aggregated (Figure S8, Supporting Information), and AS1411 released from the Au NPs is less than 5\%. The steric effect of the G-quadruplex structure of AS1411 blocks the aminothiol and protein molecules in plasma from accessing and interacting with the Au NP surfaces. Satellite-like AS1411-Au NPs/Au@PC NP was prepared by simply mixing $1.0 \mathrm{nM}$ of AS1411-Au NPs and $25 \mathrm{pM}$ of $\mathrm{Au} @ \mathrm{PC} \mathrm{NP}$ [prepared from $0.5 \mathrm{mM}$
$\mathrm{HAuCl}_{4}$ solution and $0.5 \mathrm{mM}$ catechin solution in 10 $\mathrm{mM}$ Tris-acetate ( $\mathrm{pH}$ 3.0)] in PBS. AS1411-Au NPs were self-assembled on Au@PC NP, mainly through multivalent $\Pi-\Pi$ stacking and hydrogen bonding between nucleobase-poly(catechin), although hydrophobic interactions cannot not be excluded. We note that the AS1411-Au NPs (>95\%) were bound on the Au@PC NP demonstrated by the agarose gel electrophoresis separation (data not shown), indicating ca. 40 AS1411-Au NPs on per Au@PC NP. The AS1411 molecules on the Au NPs that are opposite to the interaction side of the AS1411-Au NPs and Au@PC NP retain their targeting ability to nucleolin proteins on cell membranes. As evident from TEM images of AS1411-Au NPs/Au@PC NP, the AS1411-Au NPs are uniformly distributed on the $\mathrm{Au} @ \mathrm{PC} \quad \mathrm{NP}$ (Figure 2A(b)). Absorption spectra studies and dynamic light scattering (DLS) measurements further reveal that self-assembled AS1411-Au NPs/Au@PC NP nanocomposites are very stable in biological mimetic solution (Figure 2B and $2 \mathrm{C}$ ). Furthermore, in vitro cytotoxicity assays have revealed superior biocompatibility of AS1411-Au $\mathrm{NPs} / \mathrm{Au} @ \mathrm{PC} \quad \mathrm{NP} \quad$ (Figure S9, Supporting Information).

(A) (a)

(b)

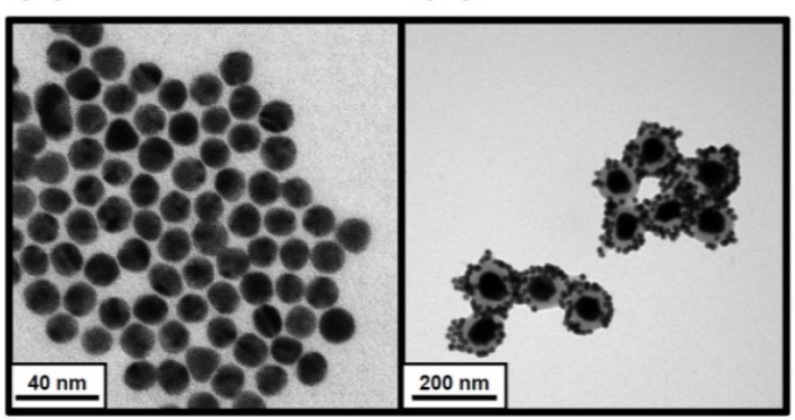

(B)

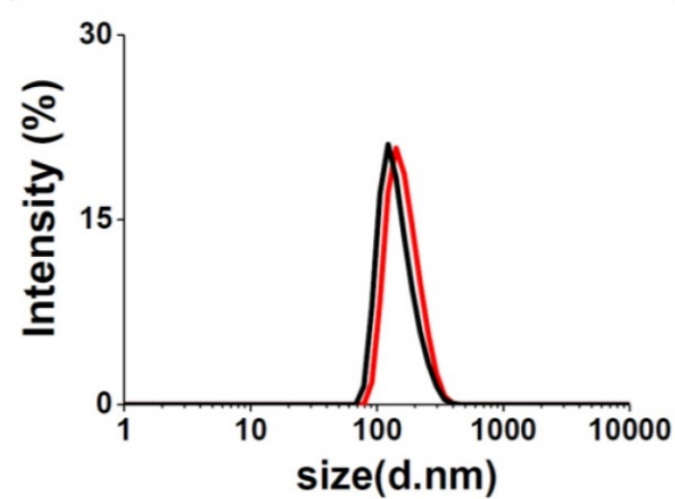

(C)

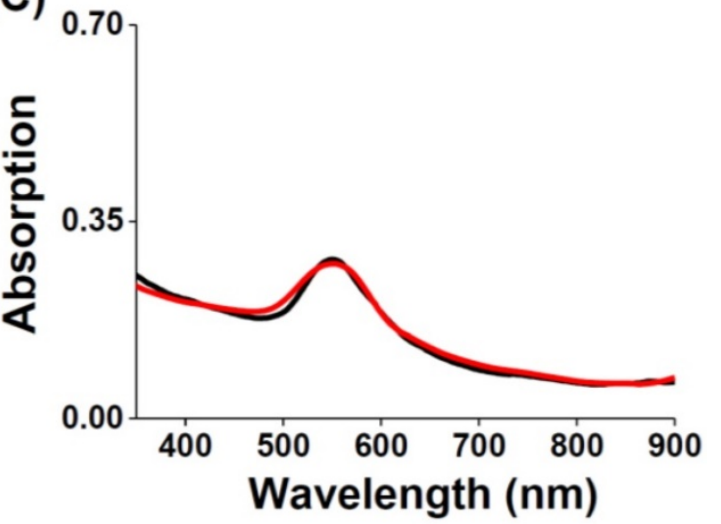

Figure 2. (A) TEM images of as-prepared (a) AS1411-Au NPs and (b) AS1411-Au NPs/Au@PC NP nanocomposites. (B) DLS spectra and (C) UV-vis absorption spectra of as-synthesized AS1411-Au NPs/Au@PC NP (2-fold diluted) in (black) DI water and (red) biological mimetic solution. 


\section{LDI-MS of AS1411-Au NPs/Au@PC NP}

Under pulsed laser irradiation of $\mathrm{Au} N P s$, photoabsorption occurs that results in desorption, fragmentation, and ionization of surface $\mathrm{Au}$ atoms and/or whole $\mathrm{Au} \mathrm{NPs,} \mathrm{through} \mathrm{photothermal}$ evaporation and Coulomb explosion processes [54-56]. The photothermal evaporation happens as a result of transfer of thermal energy to the lattice system of metallic nanoparticles, and results in the formation of neutral and charged metallic clusters upon reaching the lattice temperature $\left(T_{\ell}\right)$ [54-56]. In contrast, Coulomb explosion is the ejection of a large number of electrons from metallic nanoparticles, followed by generation of positively charged metallic cluster ions [54-56]. LDI-induced formation of $\mathrm{Au}$ cluster ions by fragmentation and ionization from $\mathrm{Au}$ NPs depends on nanoparticle properties (composition, crystallization, size, and surface ligand), environmental temperature and pressure, as well as laser parameters (wavelength, intensity, and pulse width) [57-59]. The Au NPs may transfer their adsorption laser energy to surface AS1411 ligands, and the dense "mantle" of aptamer may strongly inhibit the $\mathrm{Au} \mathrm{NPs}^{\prime}$ ejection of electrons, thereby resulting in large decreases in the $T_{\ell}$ and electron temperature $\left(T_{\mathrm{e}}\right)$. As a result, the formation of $\mathrm{Au}$ cluster ions $\left[\mathrm{Au}_{n}\right]^{+}(1 \leq n \leq 3)$ from the Au NPs is reduced to $60 \%$ when they were capped with AS1411 (Figure 3A and 3B). However, the intensity of $\mathrm{Au}$ cluster ions formed from AS1411-Au NPs is enhanced after anchoring on the Au@PC NP (Figure 3D). The AS1411-Au NPs/Au@PC NP exhibits much stronger $\mathrm{Au}$ cluster ions intensity than that of AS1411-Au NPs and Au@PC NP. This phenomenon arises mainly because of the high UV-region absorption coefficients of poly(catechin) in the nanocomposites. The poly(catechin) probably absorbs the laser energy and then transfers it to the AS1411-Au NPs, thereby facilitating formation of $\left[\mathrm{Au}_{n}\right]^{+}$cluster ions. The dense poly(catechin) layer, rich with stacked phenyl rings, may assist electron ejection from the interface of AS1411 and Au NPs, resulting in efficient formation of $\left[\mathrm{Au}_{n}\right]^{+}$cluster ions [54-56].

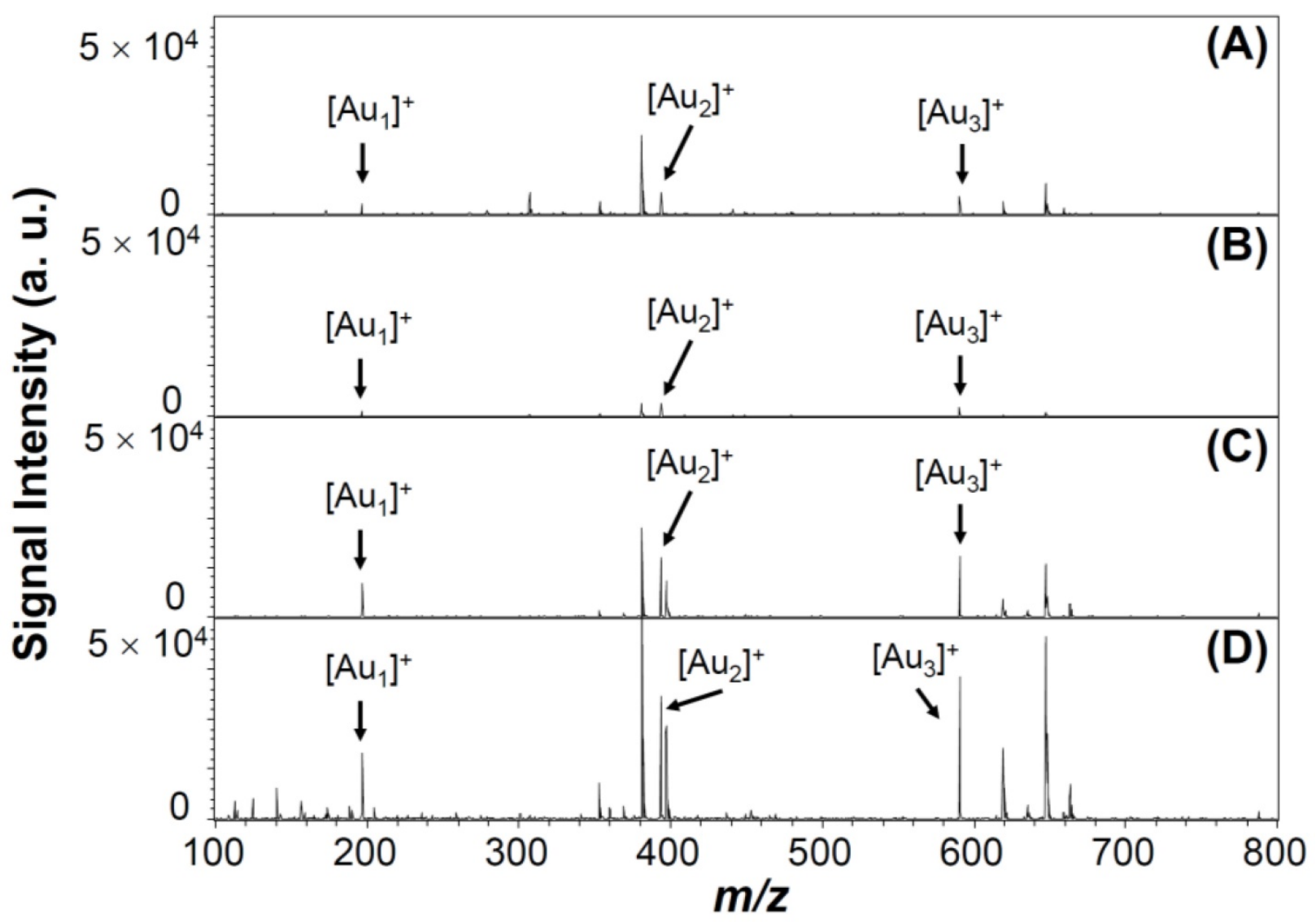

Figure 3. LDI-MS spectra of (A) Au NPs (1.0 nM), (B) AS1411-Au NPs (1.0 nM), (C) Au@PC NP (25 pM), and (D) AS1411-Au NPs/Au@PC NP ([AS1411-Au NPs] $=1.0 \mathrm{nM} ;[\mathrm{Au} @ \mathrm{PC} \mathrm{NP}]=25 \mathrm{pM})$. Signals at $\mathrm{m} / \mathrm{z}$ 196.97, 393.93, and 590.90 are assigned to $\left[\mathrm{Au}_{1}\right]^{+},\left[\mathrm{Au}_{2}\right]^{+}$, and $\left[\mathrm{Au}_{3}\right]^{+}$ions, respectively. 500 pulsed laser shots were applied at five LDI-targeted positions at a laser power density of $5.0 \times 10^{4} \mathrm{~W} \mathrm{~cm}^{-2}$. Signal intensities are plotted in arbitrary units (a. u.). 


\section{Specific Detection of Tumor Cells}

We applied the AS1411-Au NPs/Au@PC NP-LDI-MS platform to the analysis of nucleolin-overexpressing MCF-7 cells. The multivalent AS1411-Au NPs on Au@PC NP have superior cooperative affinity toward nucleolin on cell membranes [60-63], and an innately higher efficiency to produce $\mathrm{Au}$ cluster ions than that of AS1411-Au NPs. As a result, use of AS1411-Au NPs/Au@PC NP for the LDI-MS based detection of MCF-7 cells results in $\sim 4$ folded stronger $\left[\mathrm{Au}_{n}\right]^{+}$signals compared to that using AS1411-Au NPs (Figure 4a and 4b). The AS1411-Au NPs/Au@PC NP probe allows detection of MCF-7 cells as low as $\sim 100$ cells $\mathrm{mL}^{-1}$ through monitoring the $\left[\mathrm{Au}_{1}\right]^{+}$signal by LDI-MS (Figure S10, Supporting Information). As a control, random DNA (rDNA)-conjugated $\mathrm{Au} \mathrm{NPs} / \mathrm{Au} @ \mathrm{PC} \mathrm{NP}$ for the analysis of MCF-7 cells show negligible $\left[\mathrm{Au}_{n}\right]^{+}$signals compared with that of AS1411-Au NPs/Au@PC NP (Figure 4c), revealing the high specificity provided by AS1411. The self-assembled rDNA-Au NPs/Au@PC NP show very similar structure and UV-vis absorption to AS1411-Au NPs/Au@PC NP (Figure 2 and Figure S11, Supporting Information). The signal from random DNA (rDNA)-conjugated $\mathrm{Au}$ NPs/Au@PC NP (rDNA-Au NPs/Au@PC NP) for the detection of MCF-7 cells is probably due to the nonspecific interaction of the nanocomposites with the cells or plate substrate.

To further show the specificity of the assay, the AS1411-Au NPs/Au@PC NP-LDI-MS platform was applied for analysis of two other cell lines, MCF-10A (normal mammary epithelial cells) and MDA-MB-231 (breast adenocarcinoma cells). $\left[\mathrm{Au}_{1}\right]^{+}$signal intensity obtained for MCF-7 cell line is about 7.3 fold, and MDA-MB-231 cell line is about 15.5-fold higher than that obtained for normal-like MCF-10A cell line (Figure S12, Supporting Information). This result is consistent with that obtained from western blotting analysis (Figure S13, Supporting Information). Moreover, the intensity of the $\left[\mathrm{Au}_{1}\right]^{+}$signal decreases with the increase in the ratio of cell numbers of MCF-10A to MCF-7 in the co-culture samples (Figure S14, Supporting Information). Most human breast cancer cells overexpress nucleolin; however, MCF-7 cells show lower overexpression of nucleolin than that of MDA-MB-231 cells [45, 64]. Reports show that, nucleolin located on the breast cell membrane acts as a receptor for several oncogenic ligands, and transformation in the expression and localization of nucleolin can induce many oncogenic effects, such as stabilization of AKT, Bcl-2, Bcl-XL, and IL-2 mRNAs $[64,65]$. Analysis of tumor cells by other mass spectrometry techniques require sample pretreatment, labeling and purification, and are time consuming, and difficult for specific targeting of tumor cells for quantitation. In contrast, our newly developed platform is more sensitive, specific, and simple, moreover it shows great potential for quantification of tumor cells. Cell surface nucleolin is involved in the proliferation and angiogenesis of tumor cells [66]; and accordingly, nucleolin have become an attractive tumor marker and a target for anti-tumor immunotherapies [67]. Therefore, our sensing platform can be applied for the determination of nucleolin levels in tumor cells for analysis of the degree of malignancy and metastasis.

\section{Tumor Tissue Imaging}

LDI-MS-based tissue imaging techniques, using a suitable organic matrix or nanoparticle substrates, have been widely used for the analysis of small molecules such as lipid components and drugs [12-14, 32-39]. However, reports on the analysis of proteins on cell membranes by LDI-MS is rare. Here, we applied the AS1411-Au NPs/Au@PC NP-LDI-MS platform for analysis of nucleolin expression in a typical tissue microarray by monitoring the $\left[\mathrm{Au}_{1}\right]^{+}$ signal. The AS1411-Au NPs/Au@PC NPs labeled breast carcinoma or normal tissues were analyzed by LDI-MS. LDI-MS images in Figure S15, Supporting Information, show the total intensity of $\left[\mathrm{Au}_{1}\right]^{+}$signal obtained for breast carcinoma microarray tissue section was over 20 -fold higher than that of normal breast microarray tissue section. Our results demonstrate that our AS1411-Au NPs/Au@PC NP-LDI-MS system can be used to analyze nucleolin expression in tissue samples. The resolution of our LDI-MS imaging system $\sim 150 \mu \mathrm{m}$ that does not match up to fluorescence imaging, however, the strong binding of the nanocomposite with high specificity to the targeted membrane proteins and high signal amplification by $\mathrm{Au}$ NPs enable our platform to achieve high targeting ability and sensitivity.

We further applied the AS1411-Au NPs/Au@PC NP-LDI-MS imaging system to analyze the tissue sections of human breast invasive ductal carcinoma; from a 47 years old female, and normal human breast tissue sections from a 33 years old female. Representative MS images generated through monitoring of $\left[\mathrm{Au}_{1}\right]^{+}$signal intensity clearly indicate the tumor tissues relative to normal tissues have much stronger signal intensities (Figure 5B), signifying that our newly developed MSI platform can be employed for the diagnosis of malignancies. Further analysis of nucleolin expression and distribution in breast tissue sections by immunohistochemistry (IHC) show results consistent with those obtained through LDI-MS. The 
representative IHC image of breast tumor tissue clearly shows the developed brown color being deeper (Figure 5C). Traditional IHC analysis with chromogenic detection requires tedious sandwich binding and enzyme-catalytic color development (amplification) [68]. Moreover, IHC analysis is difficult for identification of co-localized multi-proteins, and its dynamic range is narrow. Our simple LDI-MS detection platform has shown a wide dynamic range ( $>3$ orders) for quantitation of tumor cells (Figure S10). Moreover, our AS1411-Au NPs/Au@PC NP-LDI-MS probe shows significant potential for the LDI-MS analysis of co-localized multi-proteins in cell membranes by functionalizing different metal (e.g. gold, silver, platinum) nanoparticles with highly recognized ligands.

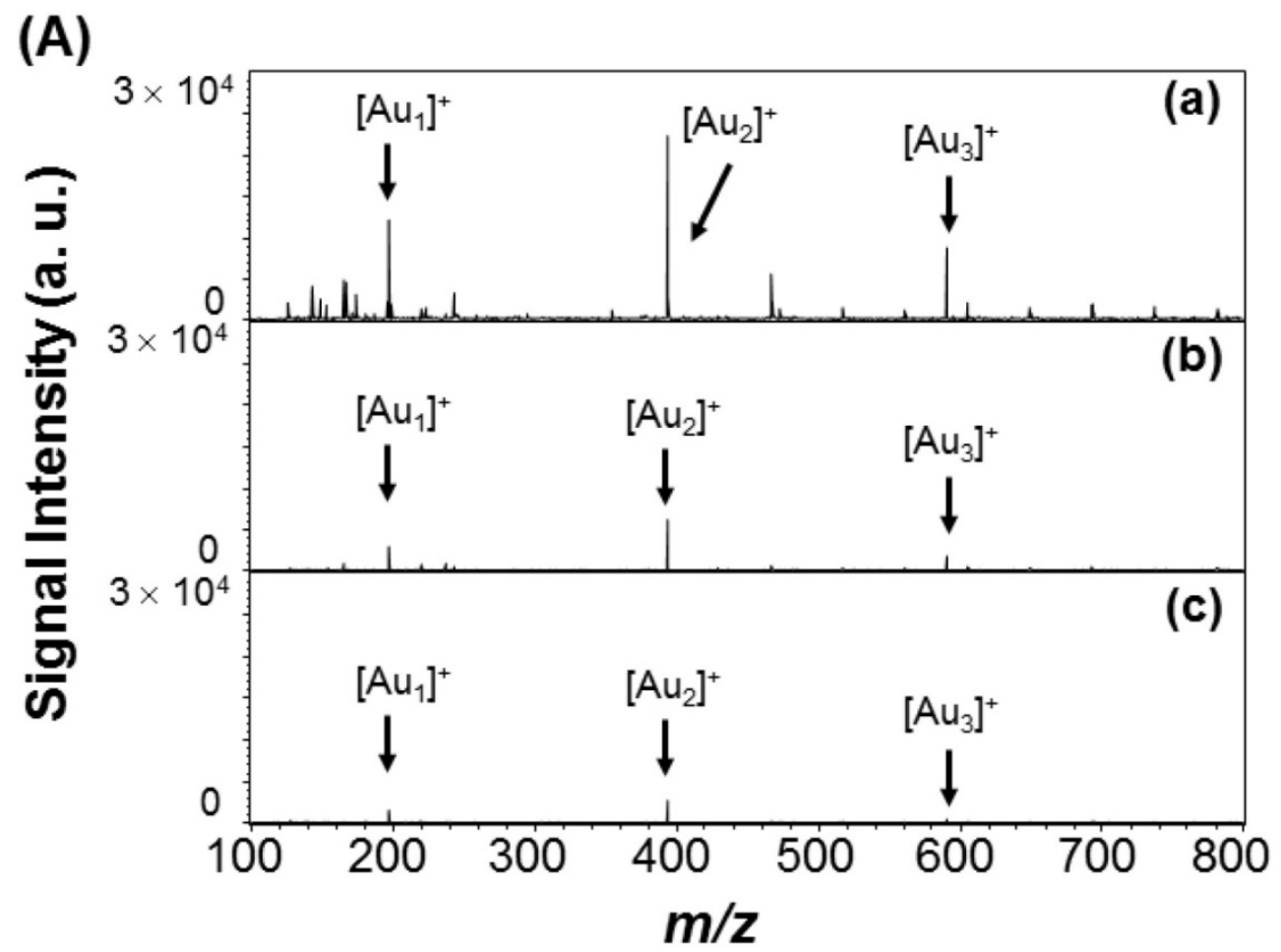

(B)

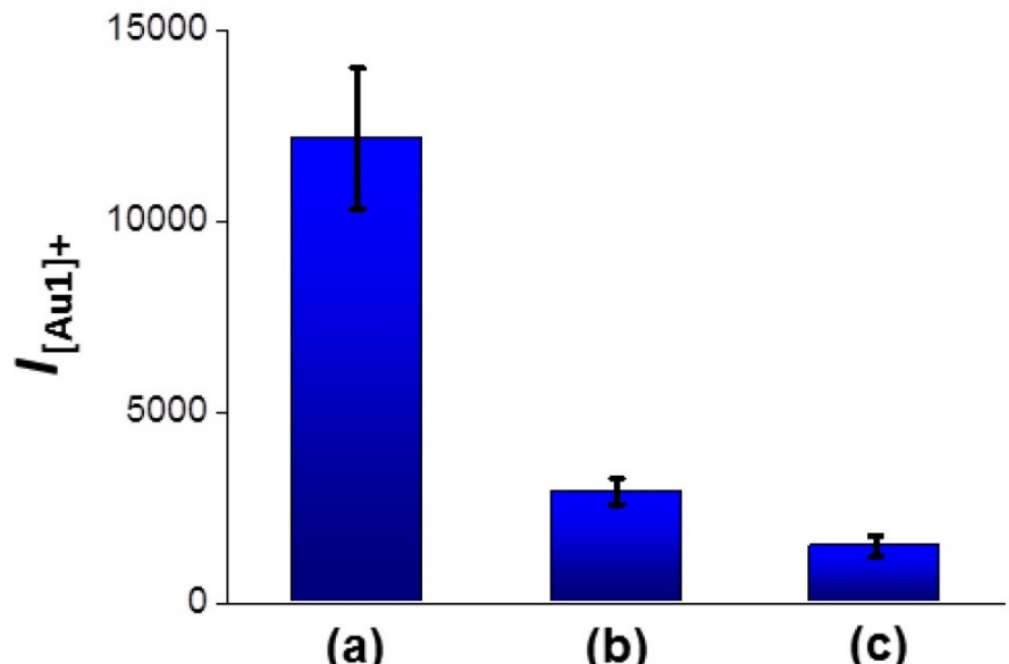

Figure 4. (A) LDI-MS spectra recorded using (a) AS1411-Au NPs/Au@PC NP ([AS1411-Au NPs] = 0.2 nM; [Au@PC NP] = 5 PM), (b) AS1411-Au NPs (0.2nM), and (c) rDNA-Au NPs/Au@PC NP ([random DNA-Au NPs] = 0.2 nM; [Au@PC NP] = 5 pM) as probes for the detection of 104 MCF-7 cells. (B) Peak intensities of [Aul $]^{+}\left(I_{[A u l]^{+}}\right)$obtained from (a) AS1411-Au NPs/Au@PC NP, (b) AS1411-Au NPs, and (c) rDNA-Au NPs/Au@PC NP after labeling of MCF-7 cells. 

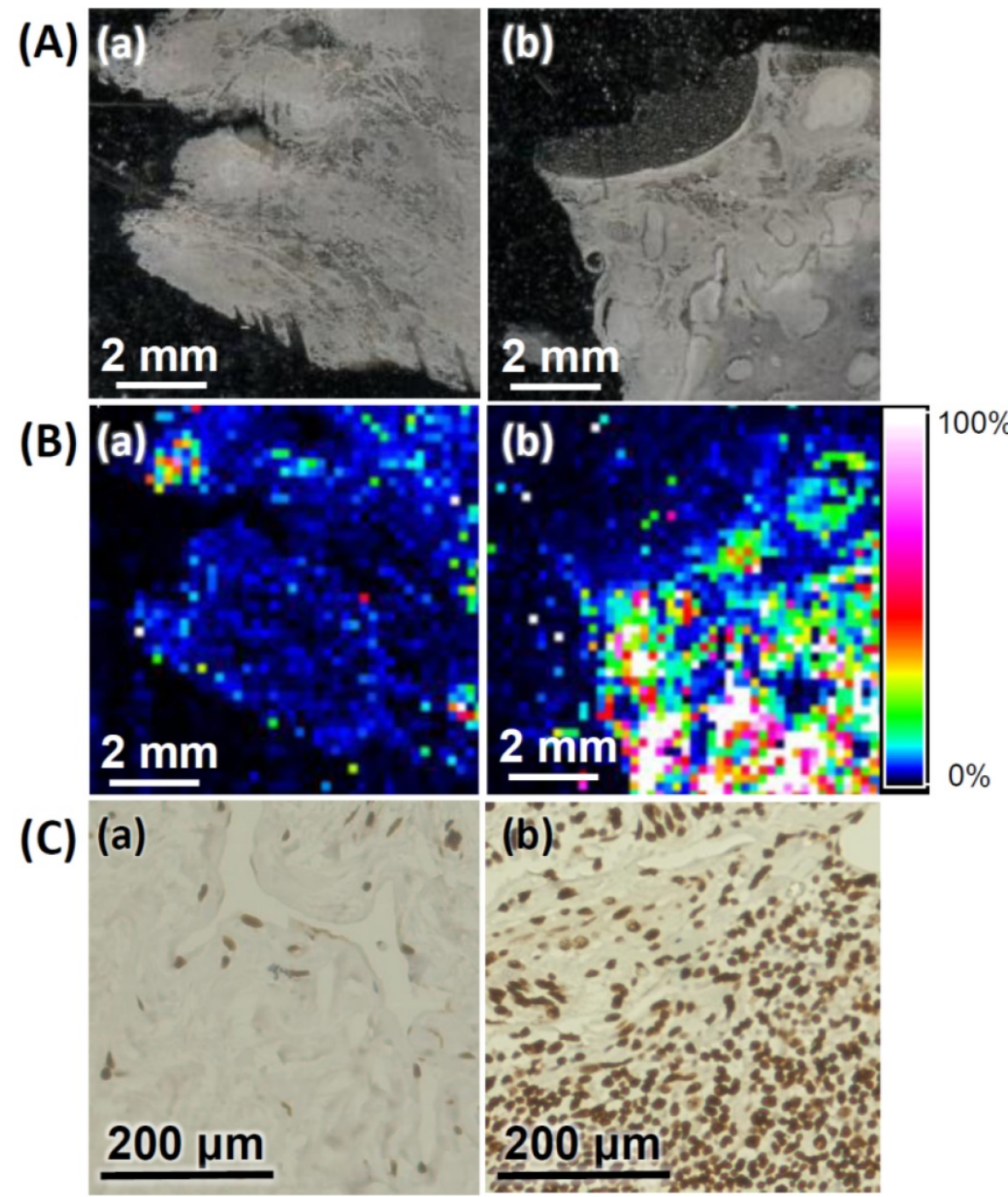

Figure 5. (A) Optical images of (a) normal breast and (b) breast tumor tissues. (B) LDI-MS images of the [Au [ ] intensity obtained for (a) normal breast and (b) breast tumor tissues after labeling with AS1411-Au NPs/Au@PC NPs. (C) Immunostaining of nucleolin in (a) normal breast and (b) tumor breast tissues. The dark brown and blue colors represent the staining of nucleolin and nuclei, respectively. Parameters of LDI-MS imaging: $60 \times 60$ pixel, laser spot size: $30 \mu \mathrm{m}$, and step size: $150 \mu \mathrm{m}$. Other conditions were the same as those described in Figure 4.

\section{Conclusions}

We synthesized Au@PC NPs, each with an Au NP core stabilized with a dense poly(catechin) shell. The molar ratio of catechin to $\mathrm{Au}$ ions and the $\mathrm{pH}$ value highly influence the size and morphology of the Au-core, and the density and thickness of the poly(catechin) shell in the synthesis of Au@PC NPs. The poly(catechin) shell on the Au NP is an excellent matrix for immobilization of AS1411 aptamer-modified Au NPs, and acts an efficient pulse light energy transducer. The self-assembled nanosatellite AS1411-Au NPs/Au@PC NP possess high specificity toward the target nucleolin overexpressed tumor cells. Compared to our previous aptamer-Au NPs modified graphene oxide nanocomposite for protein targeting [69], the preparation of self-assembled and label-free
AS1411-Au NPs/Au@PC NP is relatively straightforward. Moreover, the AS1411-Au $\mathrm{NPs} / \mathrm{Au} @ P C \mathrm{NP}$ provide a huge signal of $\left[\mathrm{Au}_{n}\right]^{+}$ cluster ions in the LDI-MS analysis. We also demonstrated the AS1411-Au NPs/Au@PC NP-LDI-MS as a sensitive platform for detection of tumor cells and tumor tissue imaging. In the future, we will extend our aptamer-Au NPs/Au@PC NP nanocomposite for theragnosis applications by loading anti-tumor drugs on the poly(catechin) shell.

\section{Supplementary Material}

Supplementary experimental section, table and figures. http://www.ntno.org/v01p0141s1.pdf

\section{Acknowledgements}

We are grateful to the Ministry of Science and 
Technology (MOST) of Taiwan for providing financial support for this study under contracts 104-2923-M-002-006-MY3， 104-2113-M-002-008-MY3 and 104-2628-M-019-001-MY3. The assistance of Ms. Ya-Yun Yang and Ms. Ching-Yen Lin from the Instrument Center of National Taiwan University (NTU) for TEM measurement is appreciated. We would like to thank the Proteomics MS Core Facility at Department of Chemistry at National Taiwan University for assistance with the LDI-MS measurements.

\section{Competing Interests}

The authors have declared that no competing interest exists.

\section{References}

1. Ong $\mathrm{SH}$, Jin $\mathrm{XC}$, Jayasooriah, Sinniah R. Image analysis of tissue sections. Comput Biol Med. 1996; 26: 269-70.

2. He L, Long LR, Antani $S$, et al. Histology image analysis for carcinoma detection and grading. Comput Methods Programs Biomed. 2012; 107: 538-56.

3. Fass L. Imaging and cancer: a review. Mol Oncol. 2008; 2: 115-52.

4. Vakoc BJ, Fukumura D, Jain RK, et al. Cancer imaging by optical coherence tomography: preclinical progress and clinical potential. Nat Rev Cancer. 2012; 12: $363-8$

5. Conway JRW, Carragher NO, Timpson P. Developments in preclinical cancer imaging: innovating the discovery of therapeutics. Nat Rev Cancer. 2014; 14: $314-28$

6. Weissleder R, Nahrendorf M. Advancing biomedical imaging. Proc Natl Acad Sci U S A. 2015; 112: 14424-8.

7. Chughtai K, Heeren RMA. Mass spectrometric imaging for biomedical tissue analysis. Chem Rev. 2010; 110: 3237-77.

8. Gessel MM, Norris JL, Caprioli RM. MALDI imaging mass spectrometry: spatial molecular analysis to enable a new age of discovery. J Proteomics. 2014; 107: 71-82

9. Cole LM, Clench MR. Mass spectrometry imaging tools in oncology. Biomark Med. 2015; 9: 863-8.

10. Laskin J, Lanekoff I. Ambient mass spectrometry imaging using direct liquid extraction techniques. Anal Chem. 2016; 88: 52-73.

11. Spengler B. Mass spectrometry imaging of biomolecular information. Anal Chem. 2015; 87: 64-82

12. Fernández JA, Ochoa B, Fresnedo $O$, et al. Matrix-assisted laser desorption ionization imaging mass spectrometry in lipidomics. Anal Bioanal Chem. 2011; 401: 29-51.

13. Norris JL, Caprioli RM. Analysis of tissue specimens by matrix-assisted laser desorption/ionization imaging mass spectrometry in biological and clinical research. Chem Rev. 2013; 113: 2309-42.

14. Cillero-Pastor B, Heeren RM. Matrix-assisted laser desorption ionization mass spectrometry imaging for peptide and protein analyses: a critical review of on-tissue digestion. J Proteome Res. 2014; 13: 325-35.

15. Hölscher D, Shroff R, Knop $K$, et al. Matrix-free UV-laser desorption/ionization (LDI) mass spectrometric imaging at the single-cell level: distribution of secondary metabolites of Arabidopsis thaliana and Hypericum species. Plant J. 2009; 60: 907-18.

16. Yan B, Kim ST, Kim CS, et al. Multiplexed imaging of nanoparticles in tissues using laser desorption/ionization mass spectrometry. J Am Chem Soc. 2013; 135: 12564-7.

17. Nemes P, Vertes A. Laser ablation electrospray ionization for atmospheric pressure, in vivo, and imaging mass spectrometry. Anal Chem. 2007; 79: 8098-106.

18. Nemes P, Woods AS, Vertes A. Simultaneous imaging of small metabolites and lipids in rat brain tissues at atmospheric pressure by laser ablation electrospray ionization mass spectrometry. Anal Chem. 2010; 82: 982-8.

19. Wu C, Dill AL, Eberlin LS, et al. Mass spectrometry imaging under ambient conditions. Mass Spectrom Rev. 2013; 32: 218-43.

20. Wiseman JM, Ifa DR, Zhu Y, et al. Desorption electrospray ionization mass spectrometry: imaging drugs and metabolites in tissues. Proc Natl Acad Sci U S A. 2008; 105: 18120-5.

21. Wiseman JM, Puolitaival SM, Takáts Z, et al. Mass spectrometric profiling of intact biological tissue by using desorption electrospray ionization. Angew Chem Int Ed. 2005; 44: 7094-7.

22. Laskin J, Heath BS, Roach PJ, et al. Tissue imaging using nanospray desorption electrospray ionization mass spectrometry. Anal Chem. 2012; 84: 141-8.
23. Lanekoff I, Thomas M, Carson JP, et al. Imaging nicotine in rat brain tissue by use of nanospray desorption electrospray ionization mass spectrometry. Anal Chem. 2013; 85: 882-9.

24. Calligaris D, Caragacianu D, Liu X, et al. Application of desorption electrospray ionization mass spectrometry imaging in breast cancer margin analysis. Proc Natl Acad Sci U S A. 2014; 111: 15184-9.

25. Hsu C-C, Chou P-T, Zare RN. Imaging of proteins in tissue samples using nanospray desorption electrospray ionization mass spectrometry. Anal. Chem. 2015; 87: 11171-5.

26. Boxer SG, Kraft ML, Weber PK. Advances in imaging secondary ion mass spectrometry for biological samples. Annu Rev Biophys. 2009; 38: 53-74.

27. Passarelli MK, Winograd N. Lipid imaging with time-of-flight secondary ion mass spectrometry (ToF-SIMS). Biochim Biophys Acta Mol Cell Biol Lipids. 2011; 1811: 976-90.

28. Passarelli MK, Ewing AG, Winograd N. Single-cell lipidomics: characterizing and imaging lipids on the surface of individual Aplysia californica neurons with cluster secondary ion mass spectrometry. Anal Chem. 2013; 85: 2231-8.

29. Kraft ML, Klitzing HA. Imaging lipids with secondary ion mass spectrometry. Biochim Biophys Acta Mol Cell Biol Lipids. 2014; 1841: 1108-19.

30. Hou S, Sikora KN, Tang R, et al. Quantitative differentiation of cell surface-bound and internalized cationic gold nanoparticles using mass spectrometry. ACS Nano. 2016; 10: 6731-6736.

31. Chen $\mathrm{S}$, Xiong $\mathrm{C}$, Liu $\mathrm{H}$, et al. Mass spectrometry imaging reveals the sub-organ distribution of carbon nanomaterials. Nat Nanotechnol. 2015; 10: $176-82$.

32. Arakawa R, Kawasaki H. Functionalized nanoparticles and nanostructured surfaces for surface-assisted laser desorption/ionization mass spectrometry. Anal Sci. 2010; 26: 1229-40.

33. Chiang C-K, Chen W-T, Chang H-T. Nanoparticle-based mass spectrometry for the analysis of biomolecules. Chem Soc Rev. 2011; 40: 1269-81.

34. Pilolli R, Palmisano F, Cioffi N. Gold nanomaterials as a new tool for bioanalytical applications of laser desorption ionization mass spectrometry. Anal Bioanal Chem. 2012; 402: 601-23

35. Sekuła J, Nizioł J, Rode W, et al. Silver nanostructures in laser desorption/ionization mass spectrometry and mass spectrometry imaging. Analyst. 2015; 140: 6195-209.

36. Tsao C-W, Yang Z-J. High sensitivity and high detection specificity of gold-nanoparticle-grafted nanostructured silicon mass spectrometry for glucose analysis. ACS Appl Mater Interfaces. 2015; 7: 22630-7.

37. Xu G, Liu S, Peng J, et al. Facile synthesis of gold@graphitized mesoporous silica nanocomposite and its surface-assisted laser desorption/ionization for time-of-flight mass spectroscopy. ACS Appl Mater Interfaces. 2015; 7: 2032-8.

38. Abdelhamid HN, Wu H-F. Gold nanoparticles assisted laser desorption/ionization mass spectrometry and applications: from simple molecules to intact cells. Anal Bioanal Chem. 2016; 408: 4485-502.

39. Hinman SS, Chen C-Y, Duan J, et al. Calcinated gold nanoparticle arrays for on-chip, multiplexed and matrix-free mass spectrometric analysis of peptides and small molecules. Nanoscale. 2016; 8: 1665-75.

40. Shrivas K, Hayasaka T, Sugiura Y, et al. Method for simultaneous imaging of endogenous low molecular weight metabolites in mouse brain using $\mathrm{TiO}_{2}$ nanoparticles in nanoparticle-assisted laser desorption/ionization-imaging mass spectrometry. Anal Chem. 2011; 83: 7283-9.

41. Morosi L, Spinelli P, Zucchetti M, et al. Determination of paclitaxel distribution in solid tumors by nano-particle assisted laser desorption ionization mass spectrometry imaging. PLoS One. 2013; 8: e72532.

42. Sekula J, Niziol J, Rode W, et al. Gold nanoparticle-enhanced target (AuNPET) as universal solution for laser desorption/ionization mass spectrometry analysis and imaging of low molecular weight compounds. Anal Chim Acta. 2015; 875: 61-72.

43. Nizioł J, Ossolin $\square$ ski K, Ossolin $\square$ ski T, et al. Surface-transfer mass spectrometry imaging of renal tissue on gold nanoparticle enhanced target. Anal Chem. 2016; 88: 7365-71.

44. Otake Y, Soundararajan S, Sengupta TK, et al. Overexpression of nucleolin in chronic lymphocytic leukemia cells induces stabilization of $b c l 2$ mRNA. Blood. 2007; 109: 3069-75.

45. Soundararajan $\mathrm{S}$, Chen $\mathrm{W}$, Spicer EK, et al. The nucleolin targeting aptamer AS1411 destabilizes $\mathrm{Bcl}$-2 messenger RNA in human breast cancer cells. Cancer Res. 2008; 68: 2358-65.

46. Hanakahi LA, Sun H, Maizels N. High affinity interactions of nucleolin with G-G-paired rDNA. J Biol Chem. 1999; 274: 15908-12.

47. Huang S-S, Wei S-C, Chang H-T, et al. Gold nanoparticles modified with self-assembled hybrid monolayer of triblock aptamers as a photoreversible anticoagulant. J Control Release. 2016; 221: 9-17.

48. Pei H, Li F, Wan Y, et al. Designed diblock oligonucleotide for the synthesis of spatially isolated and highly hybridizable functionalization of DNA-gold nanoparticle nanoconjugates. J Am Chem Soc. 2012; 134: 11876-9.

49. Wang W, Ding X, He M, et al. Kinetic adsorption profile and conformation evolution at the DNA-gold nanoparticle interface probed by dynamic light scattering. Anal Chem. 2014; 86: 10186-92.

50. García-Viguera C, Bridle P, Bakker J. The effect of $\mathrm{pH}$ on the formation of colored compounds in model solutions containing anthocyanins, catechin, and acetaldehyde. Vitis 1994; 33: 37-40.

51. Raula M, Maity D, Rashid MH, et al. In situ formation of chiral core-shell nanostructures with raspberry-like gold cores and dense organic shells using catechin and their catalytic application. J Mater Chem. 2012; 22: 18335-44. 
52. Kumamoto $\mathrm{M}$, Sonda $\mathrm{T}$, Nagayama $\mathrm{K}$, et al. Effects of $\mathrm{pH}$ and metal ions on antioxidative activities of catechins. Biosci Biotechnol Biochem. 2001; 65: $126-32$.

53. Janeiro P, Oliveira Brett AM. Catechin electrochemical oxidation mechanisms. Anal Chim Acta. 2004; 518: 109-15.

54. Werner D, Hashimoto S. Improved working model for interpreting the excitation wavelength- and fluence-dependent response in pulsed laser-induced size reduction of aqueous gold nanoparticles. J Phys Chem C. 2011; 115: 5063-72

55. Hashimoto S, Werner D, Uwada T. Studies on the interaction of pulsed lasers with plasmonic gold nanoparticles toward light manipulation, heat management, and nanofabrication. J Photochem Photobiol C Photochem Rev. 2012; 13: 28-54.

56. McLean JA, Stumpo KA, Russell DH. Size-selected $(2-10 \mathrm{~nm})$ gold nanoparticles for matrix assisted laser desorption ionization of peptides. J Am Chem Soc. 2005; 127: 5304-5.

57. Pustovalov VK, Smetannikov AS, Zharov VP. Photothermal and accompanied phenomena of selective nanophotothermolysis with gold nanoparticles and laser pulses. Laser Phys Lett. 2008; 5: 775-92.

58. Liu Y-C, Li Y-J, Huang C-C. Information derived from cluster ions from DNA-modified gold nanoparticles under laser desorption/ionization: analysis of coverage, structure, and single-nucleotide polymorphism. Anal Chem. 2013; 85: 1021-8.

59. Li Y-J, Chiu W-J, Unnikrishnan B, et al. Monitoring thrombin generation and screening anticoagulants through pulse laser-induced fragmentation of biofunctional nanogold on cellulose membranes. ACS Appl Mater Interfaces. 2014; 6: 15253-61.

60. Xiong $\mathrm{X}, \mathrm{Lv} \mathrm{Y}, \mathrm{Chen} \mathrm{T}$, et al. Nucleic acid aptamers for living cell analysis. Annu Rev Anal Chem. 2014; 7: 405-26.

61. Liu Z, Zhao H, He L, et al. Aptamer density dependent cellular uptake of lipid-capped polymer nanoparticles for polyvalent targeted delivery of vinorelbine to cancer cells. RSC Adv. 2015; 5: 16931-9.

62. Ocsoy I, Gulbakan B, Shukoor MI, et al. Aptamer-conjugated multifunctional nanoflowers as a platform for targeting, capture, and detection in laser desorption ionization mass spectrometry. ACS Nano. 2013; 7: 417-27.

63. Hasegawa H, Savory N, Abe K, Ikebukuro K. Methods for improving aptamer binding affinity. Molecules. 2016; 21: 421.

64. Chen C-Y, Gherzi R, Andersen JS, et al. Nucleolin and YB-1 are required for JNK-mediated interleukin-2 mRNA stabilization during T-cell activation. Genes Dev. 2000; 14: 1236-48.

65. Palmieri D, Richmond T, Piovan C, et al. Human anti-nucleolin recombinant immunoagent for cancer therapy. Proc Natl Acad Sci U S A. 2015; 112: 9418-23.

66. Destouches D, El Khoury D, Hamma-Kourbali Y, et al. Suppression of tumor growth and angiogenesis by a specific antagonist of the cell-surface expressed nucleolin. PLoS One 2008; 3. e2518.

67. Koutsioumpa M, Papadimitriou E. Cell surface nucleolin as a target for anti-cancer therapies. Recent Pat Anticancer Drug Discov. 2014; 9:137-52.

68. Miettinen M. Immunohistochemistry of soft tissue tumours - review with emphasis on 10 markers. Histopathology. 2014; 64: 101-18.

69. Huang R-C, Chiu W-J, Po-Jung Lai I, et al. Multivalent aptamer/gold nanoparticle-modified graphene oxide for mass spectrometry-based tumor tissue imaging. Sci Rep. 2015; 5: 10292.

\section{Author biography}

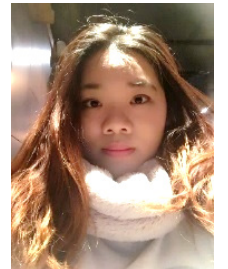

Yu-Ting Tseng is a Ph.D. candidate at the Department of Chemistry, National Taiwan University, Taiwan under the supervision of Dr. Huan-Tsung Chang. She received her Bachelor of Science Degree in Food Science (2011) and Master of Science Degree in Institute for Bioscience and Biotechnology (2013) at National Taiwan Ocean University (NTOU). Her research interest is synthesis of functional nanocomposites for biosensor and nanodrug applications.

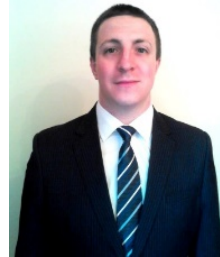

Scott G. Harroun is a Ph.D. in Chemistry student at Université de Montréal, Montréal, QC, Canada. He previously worked as a Research Assistant in the Department of Chemistry, National Taiwan University, Taipei, Taiwan. Before that, he earned his M.Sc. in Applied Science and B.Sc. (Honours) in Chemistry degrees at Saint Mary's University, Halifax, NS, Canada. He has co-authored more than 15 publications, and has won several conference awards and scholarships, including an Alexander Graham Bell Canada Graduate Scholarship from the Natural Sciences and Engineering Research Council of Canada (NSERC) for his doctoral studies. His research interests include surface-enhanced Raman spectroscopy (SERS), DNA nanotechnology, and bioanalytical applications of nanomaterials.

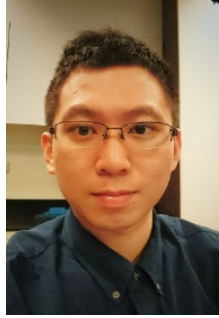

Chien-Wei $\mathbf{W u}$ is currently doing his Doctoral studies at the Department of Chemistry, National Taiwan University, Taiwan under the supervision of Dr. Huan-Tsung Chang. He received his M. S. in the department of Bioscience and biotechnology at National Taiwan Ocean University (NTOU) in 2015. His research interest is synthesis of functional nanomateria for energy storage, conversion and biosensor applications.

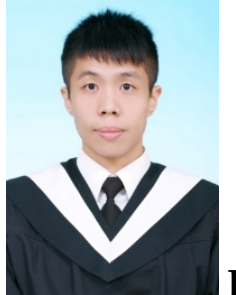

Ju-Yi Mao obtained his Master of Science Degree from the Department of Bioscience and Biotechnology, National Taiwan Ocean University, Taiwan (2016). His master thesis is on "Tuning the Orientation of Proteins on the Surface of Nanoparticles Through Genetic Engineering for Detection of HPV Virus" under the co-supervision of Dr. Han-Jia Lin and Dr. Chih-Ching Huang. Currently, $\mathrm{He}$ is a $\mathrm{Ph}$. D. student enrolled in the Doctoral Degree Program in Marine Biotechnology in National Taiwan Ocean University under the supervision of Dr. Chih-Ching Huang. He is currently 
committed in development of protein engineering nanomaterials for DNA detection systems.

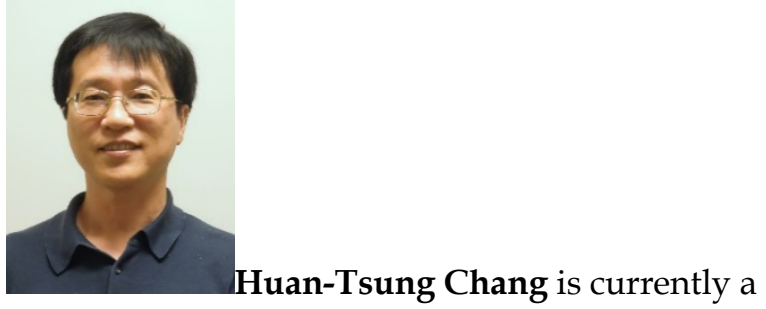

Professor of the Department of Chemistry, National Taiwan University. He obtained his $\mathrm{PhD}$ from the Department of Chemistry, Iowa State University, in 1994 with Dr Edward S. Yeung. His current research interests include nanotechnology, green chemistry, biosensors, and mass spectrometry.

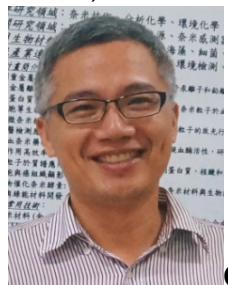

Chih-Ching Huang is a Professor at the Department of Bioscience and Biotechnology, National Taiwan Ocean University, Taiwan. He received his $\mathrm{PhD}$ degree in Analytical Chemistry from the Department of Chemistry under the supervision of Dr. Huan-Tsung Chang, National Taiwan University, Taiwan (2004). He worked as Postdoctoral fellow at the same laboratory (2006-2008). In 2008, he joined the Department of Bioscience and Biotechnology, National Taiwan Ocean University, Taiwan. His research work is mainly focused on development of nanosensors and nanodrugs. 